Social Work \& Education

C SW\&E, 2019
Олексюк, Н. (2019). Соціальна реабілітація як напрям соціальної роботи з засудженими в установах виконання покарань України, Social Work and Education, Vol. 6, No. 1., pp. 40-50. DOI:

10.25128/2520-6230.19.1.4
DOI: $10.25128 / 2520-6230.19 .1 .4$

\begin{tabular}{|c|c|}
\hline \multicolumn{2}{|l|}{ ๑ SWEE, 2019} \\
\hline & СОЦІАЛЬНА РЕАБІЛІТАЦІЯ ЯК \\
\hline УДК 364.07 & НАПРЯМ СОЦІАЛЬНОӤ РОБОТИ \\
\hline DOI: $10.25128 / 2520-6230.19 .1 .4$ & $\begin{array}{c}\text { З ЗАСУДЖЕНИМИ В } \\
\text { УСТАНОВАХ ВИКОНАННЯ }\end{array}$ \\
\hline & $\begin{array}{l}\text { УСТАНОВАХ ВИКОНАННЯ } \\
\text { ПОКАРАНЬ УКРАЇНИ }\end{array}$ \\
\hline
\end{tabular}

Наталія Олексюк, доктор педагогічних наук, професор, професор кафедри соціальної педагогіки і соиіальної роботи

Тернопільський начіональний педагогічний університет імені Володимира Гнатюка м. Тернопіль, Україна nataliva_oleksiuk@ukr.net

ORCIDiD 0000-0002-1538-1470

Article history:

Received: December 27, 2018

1st Revision: Febuary 21, 2019

Accepted: March 30, 2019
АНОТАЦЯ. У статті зазначено, що злочинність є однією значущих соціальних проблем, яка загрожує суспільному порядку, безпеці та стабільності функціонування держави. Схарактеризовано особливості перебування засуджених в умовах установи виконання покарань. Вказано, що на різні аспекти поведінки ув'язнених позитивно впливає зміцнення їх соціально-корисних зв'язків. Обгрунтовано, що одним із основних чинників виправлення осіб, які скоїли злочин, є соціальна робота $з$ ними - професійна комплексна діяльність соціального захисту засуджених, результатом чого $\epsilon$ створення умов для їх позитивного функціонування. Зазначено, що соціальна робота в пенітенціарній системі спрямована на формування в засуджених сумлінного ставлення до праці, прагнення до дотримання ними вимог законів, а також закріплення у них законослухняної поведінки як в колонії, так і за їі межами. Виявлено, що зміст соціальної реабілітації в установах виконання покарань визначається особистісними характеристиками засуджених, важкістю скоєних ними злочинів, якістю соціальних зв'язків та можливостями соціального працівника в пенітенціарній системі. На основі аналізу наукових досліджень визначено рівні (низький, середній, високий) соціальної реабілітації засуджених. Схарактеризовано найбільш результативні методи ресоціалізації (вивчення документів, бесіда, спостереження, аналіз медичних даних і динаміки розвитку особистості, незалежні характеристики, переконання, навіювання, регулювання психологічних спілкувань тощо), а також вказано, що ефективними іiі засобами є: світоглядне, моральне, правове, трудове, духовне, естетичне, фізичне, валеологічне виховання; загальноосвітнє й професійнотехнічне навчання; гуманне соціальне середовище; педагогічно доцільне дозвілля; гуманістична діяльність суспільно корисного спрямування; медичне, наркологічне, психіатричне обслуговування. Розкрито зміст роботи соціального працівника з засудженим напередодні закінчення терміну відбування ними покарання.

Ключові слова: злочинність; установа виконання покарань; засуджені; виправлення; соціальна робота; соціальна реабілітація; ресоціалізація. 3 надання соціальної допомоги й підтримки, здійснення 


\section{Вступ}

Кожне суспільство на шляху свого історичного становлення потерпає від проблем злочинності. Злочинність - це історично мінливе соціальне явище, система передбачених кримінальними законами діянь, що вчинюються на певній території або серед членів певних соціальних груп упродовж певного проміжку часу (Кримінально-виконавчий кодекс України, 2017). На жаль, для України сьогодні злочинність $є$ однією 3 відчутно значущих соціальних проблем, що загрожує суспільному порядку, безпеці та стабільності функціонування держави. Згідно даних прес-служби Державної служби статистики, в Україні з року в рік зростає не лише кількість злочинів, але й їх жорстокість, важкість та цинічність. За даними Міністерства юстиції України, станом на 1 січня 2018 року пенітенціарна система України охоплювала 148 установ виконання покарань, в яких утримувалося понад 172 тис. засуджених (Загальна характеристика Державної кримінально-виконавчої служби України, 2018).

Одним із основних чинників виправлення та ресоціалізації осіб, які скоїли засуджених злочинців $є$ соціальна робота 3 ними, спрямована на формування та закріплення в них під час відбування покарання сумлінного ставлення до праці, прагнення до дотримання вимог законів і галузевих нормативно-правових актів, а також законослухняної поведінки в колонії й за її межами (Пташинський, 2004, с. 17). Актуальність соціальної роботи в установах виконання покарань в нашій країні зумовлюється i тим, що людина, яка знаходиться на волі, може вирішити свою проблему шляхом іiі обговорення з різними фахівцями, до яких вона може звернутися у будь-який момент, як тільки цього побажає, а засуджений, через істотне обмеження своїх прав і свобод, не має можливості залучити когось іншого до їі вирішення. Таким чином, можна стверджувати, що соціальна робота в системі виконання покарань України відіграє дуже важливу роль щодо забезпечення засуджених необхідними умовами для життя та ресоціалізації (Білецький, 2013, с. 29).

Слід зазначити, що соціальна робота з засудженими в установах виконання покарань регламентується Конституцією України, Кримінальним кодексом України, Кримінально-виконавчим кодексом України, Кримінально-процесуальним кодексом України, нормами кримінально-виконавчого та іншого законодавства України, положеннями низки міжнародно-правових актів (Загальна характеристика Державної кримінально-виконавчої служби України, 2018).

Відрадно, що проблема соціальної роботи у сфері виконання покарань неодноразово ставала предметом досліджень вітчизняних і зарубіжних учених. Так, зміст соціальної роботи зі злочинцями розробляли І. Богатирьов, В. Василевич, О. Караман, Г. Радов, В. Синьов та ін.; принципи і напрями соціальної роботи в установах виконання покарань схарактеризовано у дослідженнях I. Копотуна, О. Осауленка, Б. Панасюка, О. Стулова, О. Ткачова, С. Халимон та ін.; особливості соціальної роботи з засудженими до позбавлення волі вивчали І. Даньшин, I. Карпець, В. Курляндський, В. Наливайко, О. Таволжанський, С. Фаренюк та ін.

Незважаючи на різноманітність напрямів наукового пошуку в означеній сфері, проблема змісту соціальної реабілітації засуджених, в тому числі - в установах виконання покарань, у вітчизняній науковій літературі розроблена недостатньо. Прогалини в науковому обгрунтуванні теоретичних й практичних засад соціальної реабілітації засуджених в установах виконання покарань зумовлені, на наш погляд, тим, що пенітенціарна система України тривалий час перебуває у стадії реформування, розширюється різноманітність злочинів, збільшується кількість їх рецидивів, що, в свою чергу, зумовлює необхідність запровадження нових підходів до соціальної роботи з засудженими. 
Актуальність проблеми та іï недостатня розробленість стали поштовхом для вибору нами напряму дослідження, метою якого є: обгрунтувати зміст соціальної реабілітації засуджених в установах виконання покарань України та виявити шляхи його оптимізації. На виконання поставленої мети спрямовано наступні завдання дослідження: схарактеризувати особливості соціальної роботи з засудженими в умовах установи виконання покарань; дослідити актуальність соціальної реабілітації осіб означеної категорії; проаналізувати зміст первинної соціальної реабілітації (ресоціалізації) засуджених, які перебувають в умовах установи виконання покарань; дослідити шляхи оптимізації соціальної реабілітації засуджених в установах виконання покарань.

\section{Методологія дослідження}

Недостатня вивченість такої специфічної галузі науково-практичних знань, як соціальна робота в пенітенціарних закладах, а також те, що вона носить інструментальний, програмний характер закладений в концепцію розвитку державної кримінально-виконавчої політики, обумовлюють необхідність дослідження наявних проблем для розробки методологічних засад, які б сприяли організації та здійсненню соціальної реабілітації засуджених. Незважаючи на розбіжності у методологічних підходах, більшість авторів (Васильченко, 2013; Караман, 2012; Степанюк, 2007) зазначають, що реабілітаційна діяльність соціального працівника в установі виконання покарань спрямована на вирішення проблем різного генезу і характеру, які виникають у засуджених. Так, серед основних проблем ув'язнених виділяють: переживання складних адаптаційних ситуацій; міжособистісні конфлікти; збереження соціально-корисних зв'язків із зовнішнім світом тощо (Лучко, 2014, с.166). Саме на ці проблеми і спрямовується діяльність соціального працівника.

\section{Основна частина}

Незважаючи на фізичну ізоляцію злочинців від інших співгромадян, особи, засуджені до позбавлення волі за вчинені кримінальні злочини, є однією з численних категорій населення, яка потребує відповідної соціальної допомоги. 3 ними має проводитися соціальна робота, спрямована на їх перевиховання та підготовку до корисного, правослухняного життя у суспільстві після звільнення від покарання (Oleksiuk, 2016, p.142).

Соціальна робота являє собою професійну діяльність, спрямовану на підтримання й надання кваліфікованої допомоги будь-якій людині, групі людей, громаді, що розширює або відновлює їх здатність до соціального функціонування, сприяє реалізації громадянських прав, запобігає соціальному виключенню. Відповідно до ст. 123 КВК України соціальна робота в установах виконання покарань України спрямована на формування та закріплення в засуджених прагнення до зайняття суспільно корисною діяльністю, сумлінного ставлення до праці, дотримання вимог законів та інших прийнятих у суспільстві правил поведінки, підвищення їх загальноосвітнього й культурного рівнів (Кримінальновиконавчий кодекс України, 2017).

Погоджуємось із твердженням В. Синьова, що соціальна робота в установах виконання покарань України - це професійна комплексна діяльність із надання соціальної допомоги та підтримки, здійснення соціального захисту засуджених, результатом чого є створення умов для соціального, позитивного функціонування й удосконалення людини, котра переступила поріг закону. Соціальна робота 3 засудженими поєднує в собі знання про суспільство й людину, має міждисциплінарний характер, що дає їй підставу використовувати досягнення різних 
наук. Таким чином, соціальну роботу в установах виконання покарань слід розглядати не як частину якої-небудь іншої роботи, а як самостійний вид діяльності, що передбачає захист інтересів і прав засудженого всіма дозволеними законом способами. Проте у процесі соціальної роботи з засудженими необхідно враховувати інші види діяльності і співвідносити ііі з певним режимним, виховним, освітнім або іншим навантаженням (Синьов, 2002, с. 44-45).

Основними завданнями соціальної роботи в установах виправної системи можна визначити: розвиток i зміцнення соціально-корисних зв'язків між ув'язненими та зовнішнім світом; зміна соціального статусу ув'язнених; допомога у налагодженні соціально-позитивних горизонтальних зв'язків 3 іншими особами; допомога в побудові такого типу відносин, які, з одного боку, відповідали б цілям виконання кримінального покарання, а 3 іншого - спричиняли б найменші фізіологічні, психологічні, етичні і соціальні втрати для засуджених; сприяння в забезпеченні прийнятних соціально-побутових умов для відбування покарання; допомога в соціальному розвитку ув'язнених, включаючи підвищення їхньої соціальної культури, розвиток соціальних потреб, зміну нормативно-ціннісної орієнтації, підвищення рівня соціального самоконтролю; сприяння ув'язненим в отриманні допомоги інших фахівців, зокрема - у сфері психології, психіатрії тощо; організація й забезпечення соціального захисту тих категорій ув'язнених, які його потребують (пенсіонери, особи з інвалідністю); допомога ув'язненим у пошуках соціально прийнятного для них середовища, соціального інтересу (робота, сім'я, релігія, мистецтво і ін.); допомога у вирішенні конфліктних ситуацій; сприяння соціально-правовій захищеності персоналу (Сидоров, 2016, с. 32-33).

Цей перелік завдань свідчить про те, що деякі 3 них властиві тільки соціальній роботі, інші $є$ суміжними між соціальною роботою й оперативною діяльністю, виховною і освітньою роботою, психологією та психіатрією. Відповідно до чинного кримінально-виконавчого законодавства основними напрямами соціальної роботи із засудженими $\epsilon$ спеціально організоване всебічне моральне, правове, трудове, естетичне, фізичне, санітарно-гігієнічне виховання, а також інші його види, що сприяють вибору засудженими такої життєвої позиції, яка відповідає правовим нормам і вимогам суспільно корисної діяльності (Олексюк, 2018, с. 86).

Під час організації соціальної роботи із засудженими необхідно враховувати, що саме позбавлення волі засуджені сприймають найбільш гостро. Суперечність покарання у вигляді позбавлення волі виявляється в тому, що є бажаною, з одного боку, швидка адаптація засуджених до умов місця позбавлення волі для проведення 3 ними ефективної соціальної роботи, а 3 іншого - повна адаптація, тобто засуджений починає вважати, що нічого надприродного в такому середовищі немає, а це у свою чергу ускладнює процес виправлення. Умови позбавлення волі деструктивно впливають на соціалізацію індивіда, тривала ізоляція ускладнює його адаптацію в нормальному соціальному середовищі. Це часто посилюється неправильним ставленням оточуючих до засуджених, що призводить до надмірного збудження чи гальмування нервових процесів і до нервових зривів. Ув'язнений починає невірно оцінювати власну поведінку та вчинки інших людей i, як наслідок, неправильно діяти, втрачаючи соціальні навички (Харченко, 2011, с. 36).

Вважаємо закономірним, що чинне кримінальне та кримінально-виконавче законодавство визначає своєю метою супровід покарання соціальною реабілітацією злочинця. Під соціальною реабілітацією вчені розуміють процес виправлення засудженого, формування у нього правослухняної поведінки, стимулювання становлення особистості на таку життєву позицію, яка відповідає соціальним нормам (Неживець, 2014, с. 20). Відповідно, під первинною соціальною реабілітацією (ресоціалізацією) вони розуміють повторне засвоєння культури 
людських стосунків, формування певних соціальних норм, ролей i функцій, надбання умінь і навичок, необхідних для їх успішної реалізації. Це, по суті, перебудова особистості у зв'язку зі зміною обставин. На наш погляд, ресоціалізація засуджених $є$ складним тривалим процесом, що включає комплекс психологопедагогічних, економічних, медичних, юридичних i організаційних заходів, спрямованих на формування у кожного із засуджених готовності до включення у звичайні умови життя суспільства після відбуття покарання (Олексюк, 2018, с. 86).

Оскільки первинна соціальна реабілітація ув'язненого має на меті формування (у разі втрати - відновлення) у нього якостей, умінь та навичок, необхідних для нормальної життєдіяльності у суспільстві, засвоєння відповідних цінностей і соціальних ролей, вироблення мотивації позитивно спрямованої життєдіяльності, основними показниками яких є психолого-педагогічні особливості засудженого, наявність життєвої стратегії та відповідна мотивація, ставлення його до негативних явищ, адаптивність, стресостійкість, комунікативність, конфліктність і агресивність, нами було визначено рівні розвитку перелічених показників первинної соціальної реабілітації (ресоціалізації) у засуджених, а саме:

- високий рівень первинної соціальної реабілітації (ресоціалізації) спостерігається у засуджених з чітко сформованою мотивацією поведінки. Вони мають адекватну самооцінку, емоційно стійкі та позитивно ставляться до самих себе; володіють високою соціальною активністю, самостійні та ініціативні; неконфліктні та неагресивні; усвідомлюють необхідність ведення здорового способу життя; мають яскраво виражене бажання оволодівати новими знаннями та прагнення застосовувати їх у практичному житті; демонструють готовність до постійного саморозвитку, самовдосконалення, розкриття творчого потенціалу, самоосвіти; легко налагоджують соціальні зв'язки;

- середній рівень первинної соціальної реабілітації (ресоціалізації) - у засуджених, які мають нестійку самооцінку, помірний рівень мотивації поведінки; ситуативно конфліктні та агресивні; ведуть достатньо активний спосіб життя, ситуативно дотримуються режиму дня; мають помірне задоволення життям; проявляють вибірковість у соціальній активності, самостійності, ініціативності; ситуативно включені в соціальне середовище; чітко усвідомлюють значення здоров’я та активності, мають достатній рівень мотивації для їх збереження; мають сформоване бажання самовдосконалення й самоосвіти; соціальні зв'язки налагоджують вибірково;

- низький рівень первинної соціальної реабілітації (ресоціалізації) - у засуджених, які є емоційно нестійкими, мають неадекватну самооцінку; не можуть прийняти зміни соціальної ситуації, не бачать мети подальшого життя, оскільки ним невдоволені; конфліктні та агресивні; характеризуються байдужим ставленням до себе, відсутністю усвідомлення необхідності збереження здоров'я та активності. Засудженим цього рівня притаманна низька соціальна активність; вони не готові до саморозвитку, самоосвіти й самовдосконалення; мають проблеми при налагодженні соціальних зв'язків (Oleksiuk, 2016, p. 145-146).

Для об'єктивної наукової характеристики процесу первинної соціальної реабілітації (ресоціалізації) слід визначити його завдання, а саме: підвищення загальноосвітнього рівня засуджених; професійне навчання або підвищення виробничої кваліфікації; охорона здоров'я, привчання до порядку i умов, встановлених в установах; нейтралізація негативних соціально-психологічних явищ, властивих концентрованому середовищу правопорушників, надмірного звикання до умов ізоляції від суспільства; забезпечення можливості і надання 
допомоги у встановленні і підтримці соціально корисних зв'язків, підготовка до звільнення (Неживець, 2014, с. 8).

Кожне 3 означених завдань передбачає застосування різноманітних технологій, форм і методів соціальної роботи. Наприклад, для відновлення і розвитку соціально-корисних зв'язків засудженого соціальний працівник може використовувати такі технології, як: розшук родичів та інших осіб, шляхом надсилання запиту в паспортний стіл органів внутрішніх справ за місцем останньої реєстрації (прописки) цих осіб; інтерв'ювання прибулих на побачення родичів 3 метою отримання додаткової інформації для підвищення ефективності соціальної роботи 3 ним; активізація зв'язку ув'язненого з його дітьми, братами або сестрами, шляхом встановлення листування з працівниками дитячих установ або родичами, на вихованні у яких вони знаходяться; сюрприз для ув'язненого - у випадку, якщо соціальний працівник знає про день народження родича ув'язненого або близької йому людини і допоможе дістати вітальну листівку або конверт, переправити адресату невеликий подарунок; відновлення соціально-корисних зв'язків засудженого 3 родичами або іншими близькими йому людьми - найкраще напередодні дня народження ув'язненого або святкового дня; подолання перешкод до надання засудженому права на побачення, отримання посилки (передачі) або телефонну розмову як $з$ тими родичами, які підтримують інтенсивні зв'язки з ним, так і 3 тими, які не контактують або недостатньо часто контактують 3 ним; налагодження чи поліпшення відносин з сім'ями ув'язнених; наявність списку і адрес засобів масової інформації, служб знайомств, які надають безкоштовні послуги в публікації оголошень, адрес глав та органів адміністрації тих адміністративних утворень, жителі яких складають основний контингент установи, що обслуговується соціальним працівником; ведення екрану динаміки соціальнокорисних зв'язків, в якому зазначаються список засуджених, чиї зв'язки підлягають активізації. Застосування описаних технологій доводить, що зміцнення соціальнокорисних зв'язків позитивно впливає на різні аспекти поведінки ув'язнених, включаючи дисципліну і виробничі показники (Неживець, 2014; Сидоров, 2016; Харченко, 2011).

Окрім того, соціальний працівник може використати й численні методи, які розробляються i активно впроваджуються в процес перевиховання засуджених пенітенціарними психологією та педагогікою, а саме: метод вивчення матеріалів особової справи засудженого та інших документів (наприклад, щоденника, листування та ін.); метод бесіди (допиту) - отримання від засудженого відомостей про його життєвий шлях, особистісної позиції і установках, відношенні до скоєного злочину та ін.; метод об'єктивного і включеного спостереження (одержання відомостей, їх аналіз про особистісні якості засуджених, їх прояв в умовах режиму); метод аналізу медичних даних (результатів фізичного та психотерапевтичного обстеження засудженого); метод аналізу впливу різних заходів впливу на засудженого з метою його перевиховання і діагностика його особистих змін; метод аналізу динаміки розвитку особистості під впливом різних засобів виховного впливу; метод незалежних характеристик, що дозволяє вивчити характерологічні особливості особистості за матеріалами, отриманими 3 різних джерел, для цілеспрямованого впливу на неї. У процесі індивідуально-виховної роботи 3 засудженими можуть застосовуватися й інші ефективні способи впливу на його особу (метод переконання, метод навіювання, метод регулювання психологічних спілкувань, метод передачі інформації та ін.). Застосування кожного з означених методів залежить від характеру вчиненого злочину, режиму та умов відбування покарання, психофізіологічних властивостей особистості (Замула, 2003, с. 66-67; Олексюк, 2018, с. 87). 
На основі аналізу зарубіжного досвіду соціальної роботи в установах виконання покарань, приходимо до висновку, що найбільш дієвими методами соціальної роботи в закордонних пенітенціарних закладах $є$ метод прогресивної системи виконання покарання і метод виправно-психологічної корекції особистості ув'язненого. Метод прогресивної системи виконання покарання - це сукупність юридичних, організаційних i виховних засобів, що забезпечують поетапне пом'якшення покарання ув'язненому у міру його виправлення, тобто стимуляцію законослухняної поведінки. Метод виправно-психологічної корекції особистості ув'язненого передбачає, що соціальний працівник лише керує, корегує і спрямовує клієнта, здійснює оцінку рівня виправлення через застосування психологічних $\mathrm{i}$ соціологічних методик, дає рекомендації щодо полегшення подальшої виправної практики ув'язненого. В обох випадках соціальний працівник надає первинну психологічну допомогу, здійснює психопрофілактику і корекцію деструктивних конфліктів та негативного сприйняття виправних впливів засудженим. Вважаємо за необхідне поширення означеного досвіду в установах виконання покарань України (Степанюк, 2007, с. 108).

Досвід працівників соціально-психологічної служби установ виконання покарань засвідчує, що ефективними засобами соціальної реабілітації ув'язнених $є$ : соціально-світоглядне, моральне, правове, трудове, духовне, естетичне, фізичне та валеологічне виховання; загальноосвітнє та професійно технічне навчання; гуманне соціальне середовище; педагогічно доцільне дозвілля; гуманістична діяльність суспільно корисного спрямування; медичне, наркологічне та психіатричне обслуговування (Oleksiuk, 2016, p.148).

Як зазначають С. Харченко, О. Караман, Н. Краснова до функцій соціального працівника в установі виконання покарань відносяться: складання спільно із засудженими і адміністрацією виправної установи план навчання і роботи в період позбавлення волі; допомога засудженим у подоланні психологічної кризи у зв'язку із знаходженням їх під арештом; сприяння в адаптації їх до середовища виправного закладу; організація вільного часу і культурного дозвілля засуджених; захист i спостереження за дотриманням прав і свобод засуджених; правова і психологічна допомога родичам ув'язненого в рішенні проблем пов'язаних з позбавленням його волі; регулювання питань оплати праці; підготовка ув'язненого до виходу на свободу, сприяння в пошуку йому житла i роботи; регулювання відносин засуджених i персоналу для уникнення владного свавілля; допомога найбільш вразливим групам і категоріям засуджених: неповнолітні, молодь, жінки, безробітні, пенсіонери, люди 3 інвалідністю і ін. (Харченко, 2011, с. 72-74). Незважаючи на такий широкий перелік функцій, основними 3 них, на наш погляд, $є$ наступні: правова допомога і підтримка засуджених; психолого-педагогічна діагностика особистості засудженого; розробка спільно з адміністрацією програм соціально психологічної і професійної реабілітації засуджених; адаптація засуджених до середовища виправного закладу (Олексюк, 2018, с. 88).

За кілька місяців до закінчення терміну відбування покарання із засудженим проводять цикл заходів соціального спрямування: він залучається до участі у роботі школи по підготовці до звільнення, де щоденні заняття з ним проводять не лише соціальні працівники установи, а й представники поліції, прокуратури, суду, трудових та громадських організацій, адвокати, лікарі; психологи установи обстежують засудженого для виявлення ступеня його психологічної готовності до життя на волі, надають необхідну консультативну допомогу; соціальні працівники сприяють відновленню позитивних соціальних зв'язків з близькими та родичами; адміністрація установи надає допомогу засудженому у вирішенні питань побутового плану та працевлаштування після звільнення, направляє необхідні запити до 
територіальних органів поліції, центрів зайнятості, соціальних служб та місцевих підприємств (Яковець, 2015, с. 58).

\section{Висновки}

Таким чином, зміст соціальної роботи з засудженими в установах виконання покарань визначається особистісними характеристиками засуджених, важкістю скоєних ними злочинів, якістю соціальних зв'язків та можливостями соціального працівника. В арсеналі соціальних працівників $є$ значне розмаїття технологій, форм, методів та засобів роботи з засудженими, які: сприятимуть розвитку і зміцненню їхніх соціально-корисних зв'язків, підвищенню соціального статусу, забезпечуватимуть соціальний захист i соціальний розвиток, формуватимуть соціально прийнятне для них середовище.

\section{Література}

Білецький, В. В. (2013). Дослідження пенітенціарного психолога. Донецьк: Східний видавничий дім, 40.

Васильченко, О.А. (2013). Соціальна робота в пенітенціарній системі: сучасний стан і перспективи розвитку. Грані. № 12. 31-37.

Загальна характеристика Державної кримінально-виконавчої служби України (станом на 31 грудня 2018 р.). Офіиійний веб-сайт Державної пенітениіарної служби України [Електронний ресурс]. Режим доступу : http://www.kvs.gov.ua/.

Замула, С. Ю., Костенко, В. А. , Мандра, В. І., Падалець, Б. В., \& Скоков, С. І. . (2003). Основи пенітенціарної педагогіки і психології : навчальний посібник. Біла Церква: ДДУПВП, Білоцерківське училище професійної підготовки працівників кримінально-виконавчої системи, 101.

Караман, О. Л. (2012). Соціально-педагогічна робота 3 неповнолітніми засудженими в пенітенціарних закладах України: монографія. Луган. нац. ун-т ім. Т. Шевченка. Луганськ, 447.

Кримінально-виконавчий кодекс України (2017). [Електрон. ресурс]. Режим доступу: http://zakon2.rada.gov. ua/laws/show/1129-15.

Лучко, С. В. (2014). Соціальна робота із засудженими як напрям функціонування пенітенціарних систем зарубіжних країн. Науковий вісник Херсонського державного університету. Серія : Юридичні науки. Вип. 4. 166-169.

Неживець, О. М. (2014). Ресоціалізація засуджених та осіб, звільнених з місць позбавлення волі: монографія. К. : Кондор, 222.

Олексюк, Н. С. (2018). Соціальна реабілітація осіб, які перебували у конфлікті із законом. Соиіальна робота: виклики сьогодення : матеріали VII Всеукраїнської науково-практичної конферениії, 26-27 квітня 2018 р., м. Тернопіль. Тернопіль, 86-88.

Oleksiuk, N. (2016). Role socialni rehabilitaci mladistveho pachatele v procesu resocializaci. Modern Science. Moderni veda. Praha. Ceska Republika. № 2. 142-148.

Пташинський, О. Б. (2004). Пенітенціарна система України: монографія. НАН України, І-т держави і права ім. В. М. Корецького. К. : Ін-т держави і права ім. В. М. Корецького НАНУ, 204.

Сидоров, В. Н. (2016). Ролі та функції соціальних працівників. Соціальна робота в Україні: перші кроки / під ред. В. Полтавця. К. : Видавничий дім «Academia», 236.

Синьов, В. (2002). Гуманістична спрямованість пенітенціарної педагогіки. Соціальна політика і соціальна робота. 1(21), 43-51.

Степанюк, А. Х.(2007). Втілення міжнародних стандартів у практику діяльності кримінально-виконавчої системи України. Академія правових наук України. Ін-т вивчення проблем злочинності. Х. : Тов. «Кроссроуд», 184. 
Харченко, С. Я., Караман, О. Л., \& Краснова Н. П. (2011). Пенітенціарна педагогіка: науково-метод. посіб. для студ. вищ. навч. закладів. Державний заклад «Луганський національний університет імені Тараса Шевченка». Луганськ: Вид-во ДЗ «ЛНУ ім.Тараса Шевченка», 329.

Яковець, І. С. (2015). Ведення випадку в роботі $з$ засудженими фахівців Служби пробації: методичні рекомендації. К.: МБФ «Міжнародний Альянс 3 ВІЛ/СНІД в Україні», 134. 


\title{
SOCIAL REHABILITATION \\ AS AN ASPECT OF SOCIAL WORK WITH CONVICTS IN THE PENAL INSTITUTIONS OF UKRAINE
}

\author{
Nataliya Oleksiuk, Doctor of Pedagogics, Professor, Professor of Department of \\ Social Pedagogy and Social Work, Ternopil National Volodymyr Hnatyuk \\ Pedagogical University, Ternopil, Ukraine
}

\begin{abstract}
The article states that crime is one of the most significant social problems that threatens the civic order, security and stability of the nation-state functions. Describes the features of the stay of convicts in the correctional facilities. Indicates that different aspects of the behavior of prisoners are positively influenced by the strengthening of their socially useful ties. Substantiates that one of the key methods of criminal rehabilitation is social work with people who committed a crime - a professional comprehensive activity in providing social assistance and support, the implementation of social protection of the convicts, which results in the creation of conditions for their positive functioning. The article notes that social work in the penitentiary system is aimed at forming a conscientious attitude towards the work of the prisoners, their desire to comply with the requirements of the laws, as well as the establishment of law-abiding behavior in the prison or outside. Reveals that the content of social rehabilitation in penitentiary institutions is determined by the personal characteristics of the convicts, the severity of their crimes, the quality of social ties and the possibilities of a social worker in the penitentiary system. The levels (low, medium, high) of social rehabilitation of the convicts are determined based on the analysis of scientific studies. The most effective methods of resocialization are described (studying documents, conversation, observation, analysis of medical data and dynamics of personality development, independent characteristics, beliefs, suggestions, regulation of psychological communication, transmission of information, etc.), and also indicates that its effective means are: ideological, moral, legal, labor, spiritual, aesthetic, physical, valeological education; general education and vocational training; humane social environment; pedagogically expedient leisure; humanistic activity of socially useful direction; medical, narcological, psychiatric care. The article reviles the content of the job of social worker with prisoners before their sentence expiration.
\end{abstract}

Keywords: crime (criminality); penal institution; convicts; correction (rehabilitation); social work; social rehabilitation; resocialization.

\section{References}

Biletskiy, V. V. (2013). Investigation of the penitentiary psychologist/ Donetsk: Eastern Publishing House. 2013. 40 s. [in Ukrainian].

Vasilchenko, O. A. (2013). Social work in the penitentiary system: the current state and prospects of development. Grani. (12). P. 31-37. [in Ukrainian].

General characteristics of the State Penitentiary Service of Ukraine (as of December 31, 2018). The Official Website of the State Penitentiary Service of Ukraine [Electronic resource]. Mode of access: http://www.kvs.gov.ua/. [in Ukrainian].

Zamula, S.Y. (2003). Fundamentals of Penitentiary Pedagogy and Psychology: Textbook / S. Y. Zamula, V. A. Kostenko, V. I. Mandra, B. V. Padalets, S. I. Skokov; Ed. V.N.Sinova Bila Tserkva: DPUVPVP, Bila Tserkva School of Professional Training of Employees of the Criminal-Executive System, 101 p. [in Ukrainian]. 
Karaman, O. L. (2012). Socio-pedagogical work with juvenile convicts in penitentiary institutions of Ukraine: monograph; Lugansk National Taras Shevchenko University. Lugansk, 447 c. [in Ukrainian].

The Criminal-Executive Code of Ukraine (2017). [Electronic resource]. Access mode: http://zakon2.rada.gov.ua / laws / show / 1129-15. [in Ukrainian].

Luchko, S. V. (2014). Social work with convicted persons as a direction of functioning of penitentiary systems of foreign countries. Scientific Bulletin of Kherson State University. Series: Law Sciences. (4), P. 166-169. [in Ukrainian].

Nezivets, O. M., Zhuk, L. A. \& Zhuk, I. L (2014). Resocialization of convicts and persons released from places of imprisonment: monograph. K.: Condor, 222 p. [in Ukrainian].

Oleksiuk, N. S. (2018). Social rehabilitation of persons who were in conflict with the law. Social work: Challenges of the present: materials of the VII All-Ukrainian scientificpractical conference, April 26-27, 2018, Ternopil city // Sb. sciences Ave. Ternopil, P. 86-88. [in Ukrainian].

Oleksiuk, N. S. (2016). The role of social rehabilitation of a juvenile offender in the process of his resocialization. Modern Science. Moderni veda. Prague. Czech Republic. (2), P. 142-148.

Ptashinsky, O. B. (2004). Penitentiary system of Ukraine: monograph; National Academy of Sciences of Ukraine, It of the state and rights to them. V. Koretsky. K.: Institute of State and Law V. Koretsky of the National Academy of Sciences of Ukraine, 204 p. [in Ukrainian].

Sidorov, V. N. (2016). Roles and functions of social workers / V. Sidorov / / Social work in Ukraine: the first steps / ed. V. Poltavets. Kh.: Publishing House «Academia», 236 p. [in Ukrainian].

Sinyov, V. (2002). Humanistic orientation of penitentiary pedagogy / V. Sinov // Social policy and social work. 1 (21), P. 43-51. [in Ukrainian].

Stepaniuk, A. H. (2007). Implementation of International Standards in the Practice of the Criminal-Executive System of Ukraine. Academy of Legal Sciences of Ukraine. Institute for the Study of Crime. X.: Comrade «Crossroads», 184 p. [in Ukrainian].

Kharchenko, S. Y., Karaman, O. L. \& Krasnov, N. P. (2011). Penitentiary pedagogy: scientific method. manual for the stud higher teach institutions; State institution «Taras Shevchenko Luhansk National University». Lugansk : View of DZ «LNU named after Taras Shevchenko», 329 p. [in Ukrainian].

Yakovets, I. S. \& Volik, A. (and others) (2015). Conducting a case in work with convicted Probation Service Specialists: Methodical Recommendations. K.: ICF «International HIV / AIDS Alliance in Ukraine», 134 p. [in Ukrainian]. 
